\title{
The effect of nitrate and phosphate availability on Emiliania huxleyi (NZEH) physiology under different $\mathrm{CO}_{2}$ scenarios
}

\author{
Mónica Rouco 1,2*, Oscar Branson 1,3, Mario Lebrato ${ }^{4}$ and M. Débora Iglesias-Rodríguez ${ }^{1,5}$ \\ ${ }^{1}$ National Oceanography Centre Southampton, School of Ocean and Earth Science, University of Southampton, Southampton, UK \\ 2 Department of Biology, Woods Hole Oceanographic Institution, Woods Hole, MA, USA \\ ${ }^{3}$ Department of Earth Sciences, University of Cambridge, Cambridge, UK \\ ${ }^{4}$ GEOMAR. Helmholtz Centre for Ocean Research Kiel, Kiel, Germany \\ ${ }^{5}$ Department of Ecology, Evolution and Marine Biology, University of California Santa Barbara, Santa Barbara, CA, USA
}

Edited by:

Benjamin Van Mooy, Woods Hole

Oceanographic Institution, USA

\section{Reviewed by:}

Shawn R. Campagna, University of

Tennessee, USA

Benjamin Van Mooy, Woods Hole

Oceanographic Institution, USA

\section{*Correspondence:}

Mónica Rouco, Department of

Biology, Woods Hole Oceanographic

Institution, 266 Woods Hole

Road, MS\#33, Woods Hole,

MA 02543-1050, USA

e-mail: mroucomolina@whoi.edu
Growth and calcification of the marine coccolithophorid Emiliania huxleyi is affected by ocean acidification and macronutrients limitation and its response varies between strains. Here we investigated the physiological performance of a highly calcified $E$. huxleyi strain, $\mathrm{NZEH}$, in a multiparametric experiment. Cells were exposed to different $\mathrm{CO}_{2}$ levels (ranging from 250 to $1314 \mu \mathrm{atm}$ ) under three nutrient conditions [nutrient replete $(R)$, nitrate limited (-N), and phosphate limited (-P)]. We focused on calcite and organic carbon quotas and on nitrate and phosphate utilization by analyzing the activity of nitrate reductase (NRase) and alkaline phosphatase (APase), respectively. Particulate inorganic $(\mathrm{PIC})$ and organic $(\mathrm{POC})$ carbon quotas increased with increasing $\mathrm{CO}_{2}$ under $R$ conditions but a different pattern was observed under nutrient limitation. The PIC:POC ratio decreased with increasing $\mathrm{CO}_{2}$ in nutrient limited cultures. Coccolith length increased with $\mathrm{CO}_{2}$ under all nutrient conditions but the coccosphere volume varied depending on the nutrient treatment. Maximum APase activity was found at $561 \mu \mathrm{atm}$ of $\mathrm{CO}_{2}(\mathrm{pH} 7.92)$ in - $\mathrm{P}$ cultures and in $\mathrm{R}$ conditions, NRase activity increased linearly with $\mathrm{CO}_{2}$. These results suggest that $E$. huxleyi's competitive ability for nutrient uptake might be altered in future high- $\mathrm{CO}_{2}$ oceans. The combined dataset will be useful in model parameterizations of the carbon cycle and ocean acidification.

Keywords: Emiliania huxleyi, ocean acidification, nutrients, alkaline phosphatase, nitrate reductase, calcification

\section{INTRODUCTION}

Since the beginning of the industrial revolution, atmospheric $\mathrm{CO}_{2}$ has increased at the fastest rate experienced by the Earth in the last 65 million years (Zachos et al., 2001). Consequently, the increase in $\mathrm{CO}_{2}$ dissolution in seawater has been altering the balance of the inorganic carbon species leading to a decrease in $\mathrm{pH}$ predicted to intensify over the next century (Raven et al., 2005). Additionally, global warming derived from an increase in greenhouse gases induces stratification of the water column reducing mixing processes that maintain nutrient supply into the euphotic zone (Sarmiento et al., 1998). Therefore, the duration and timing of nitrate and phosphate limitation and the biogeographical regions affected are likely to vary in future oceans (Sarmiento et al., 1998). Coccolithophores play a major role in the carbon cycling being an important source of calcite in the open ocean (Gehlen et al., 2007). Emiliania huxleyi is the most abundant bloom-forming coccolithophore species (Tyrrell and Merico, 2004), and its calcification process is known to be affected by variations in carbon chemistry (Riebesell et al., 2000; Iglesias-Rodriguez et al., 2008; Langer et al., 2009). However, this response varies if other environmental parameters such as nutrient availability, temperature or light are simultaneously changed (Zondervan et al., 2002; Sciandra et al., 2003; Feng et al., 2008; De Bodt et al., 2010; Borchard et al., 2011).
E. huxleyi flourishes after the demise of diatoms, when silicate, nitrate, and phosphate are limiting (Litchman et al., 2006). This ecological strategy stems from a low nutrient quota and an extremely high phosphate affinity under phosphate-limiting conditions (Riegman et al., 2000). E. huxleyi also takes up nitrogen compounds other than nitrate (Benner and Passow, 2010; Bruhn et al., 2010), and assimilates nutrients from organic sources through the controlled expression of enzymes active in specific metabolic pathways (Dyhrman and Palenik, 2003; Bruhn et al., 2010). Despite the sensitivity of E. huxleyi to $\mathrm{CO}_{2}$ (Riebesell et al., 2000; Iglesias-Rodriguez et al., 2008; Langer et al., 2009) and its diversity of nutrient acquisition pathways, the majority of contemporary work has not considered the effect of $\left[\mathrm{CO}_{2}\right]$ on the efficiency of nutrient assimilation. Previous studies have independently assessed the biogeochemical responses of E. huxleyi to high $\mathrm{CO}_{2}$ under nitrogen (Sciandra et al., 2003; Leonardos and Geider, 2005; Müller et al., 2012) or phosphorus (Borchard et al., 2011) limitation using three different E. huxleyi strains (TW1 PML, B92/11 and a strain isolated in the Raunefjord, Norway). It is well accepted that different $E$. huxleyi strains respond differently to varying $\mathrm{CO}_{2}$ levels (e.g., Langer et al., 2009). For example, the E. huxleyi NZEH strain presents contrasting calcification responses to elevated $\mathrm{CO}_{2}$ compared to other strains tested in the laboratory. Similarly, a recent field study revealed the presence 
of a heavy calcified E. huxleyi morphotype (R-morphotype) in "acidic" waters of the South Pacific Ocean, as an exception to the global correlation found between coccolithophore calcification and $\mathrm{CO}_{3}^{-2}$ concentration (Beaufort et al., 2011). Considering this biological variability and the projected changes in the extent of oligotrophic waters, studying the effect of nutrient limitation in conjunction with ocean acidification in different E. huxleyi strains is crucial.

In this study, we assessed the combined effects of elevated atmospheric $\mathrm{CO}_{2}$ and nitrate or phosphate limitation on the physiology of the E. huxleyi strain NZEH. This is a highly calcified strain bearing coccoliths that display the R-morphotype whose production appears to be resilient to ocean acidification (IglesiasRodriguez et al., 2008; Beaufort et al., 2011). We also investigated the effect of $\mathrm{CO}_{2}$ on nitrate and phosphate utilization by analyzing the activity of two enzymes involved in nutrient assimilation: alkaline phosphatase (APase), and nitrate reductase (NRase). Investigating the response of different E. huxleyi strains, and potential discrepancies between them, to environmental change is central to model the contribution of this ecologically important species to the global carbon cycle.

\section{MATERIALS AND METHODS CULTURE CONDITIONS}

Experiments were conducted in diluted batch cultures of E. huxleyi (Lohmann) W. W. Hay and H. P. Mohler, strain NZEH (CAWPO 6), isolated in 1992 in the South Pacific Ocean and obtained from the Plymouth Culture Collection (UK). Artificial sea-water (ASW) was prepared according to Kester et al. (1967) with different nitrogen and phosphorus concentrations to achieve nutrient (nitrate, phosphate)-replete $(\mathrm{R})$, nitrate-limited $(-\mathrm{N})$ and phosphate-limited (-P) conditions (Table 1). Trials were conducted prior to the experiments to ensure that $-\mathrm{N}$ and $-\mathrm{P}$ cultures reached nutrient limitation at the desired cell density, a density below levels that would alter significantly the media carbon chemistry. The three nutrient regimes were combined with different $\mathrm{CO}_{2}$ partial pressures (ranging from 250 to $1314 \mu \mathrm{atm}$ ) corresponding to pre-industrial levels and projected values for the middle and the end of the century respectively (Table 1). Medium carbonate chemistry was adjusted by additions of sodium carbonate $\left(\mathrm{Na}_{2} \mathrm{CO}_{3}\right)$ and hydrochloric acid $(\mathrm{HCl})$ to change the relative proportion of dissolved inorganic carbon (DIC) species and restore total alkalinity (TA) respectively (Riebesell et al., 2010). The conditions mimicked changes in carbonate chemistry associated with ocean acidification $\left(\mathrm{CO}_{2}\right.$ increases while TA remains constant at $\sim 2268 \pm 64.86 \mu \mathrm{mol} \mathrm{kg}^{-1}$ ) (Table 1). The culture medium was filtered through sterile $0.22 \mu \mathrm{m}$ polycarbonate filters (Millipore ${ }^{\circledR}$ Stericup $^{\mathrm{TM}}$ Filter Units). All other environmental parameters remained constant throughout the experiments: salinity $=34.00 \pm 0.40$, temperature $=$ $19.00 \pm 0.50^{\circ} \mathrm{C}, 12: 12 \mathrm{~h}$ light:dark cycle, irradiance $=120.00 \pm$ $15.00 \mu \mathrm{mol}$ photons $\mathrm{m}^{2} \mathrm{~s}^{-1}$ under Sylvania Standard F36W/135T8 white fluorescent lighting (Havells Sylvania, Newhaven, UK).

\section{INCUBATION EXPERIMENTS}

Experiments were conducted in triplicate in 4 L Nalgene ${ }^{\circledR}$ polycarbonate bottles. After the cell inoculation at an initial density of 100 cells $\mathrm{ml}^{-1}$, the bottles were completely filled to minimize headspace, closed and sealed with Parafilm ${ }^{\circledR}$ until harvested. A blank control bottle (containing no cells) was incubated alongside each treatment. A fourth replicate bottle (seeded with the same original stock culture and at the same concentration as that used in the triplicate bottle experiments) was used for daily monitoring of cell density, temperature, $\mathrm{pH}$ and irradiance, to avoid opening any of the triplicate bottles during the course of the experiment. Cell densities at the time of harvest in R cultures were 75,988 \pm 13,159 cells $\mathrm{ml}^{-1}$ depending on the treatments. The $\mathrm{R}$ cultures were harvested during exponential growth phase and did not experience nutrient limitation over the course of the experiment. The $-\mathrm{N}$ and -P cultures were harvested two days after exponential growth stopped (assessed by daily cell counts from the test bottle). This allowed cultures to be in growth-limiting conditions for 2 days (cell densities at the time of harvest were 71,587 \pm 9250 and

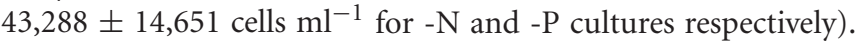
All cultures were allowed to grow for 8-10 generations, corresponding to a maximal DIC consumption of $12 \%$. This number of generations ensured that almost $100 \%$ of the cells in the cultures experience the study conditions. At time 0 (pre-inoculation) and during harvesting (always conducted $3 \mathrm{~h}$ after the beginning of the light phase), samples were collected from all experimental bottles for analysis of carbon chemistry and macronutrient concentration in the medium, particulate organic carbon (POC), $\mathrm{Ca}^{2+}$ measurements [for determination of particulate inorganic carbon (PIC)], particulate organic nitrogen (PON) and phosphorous (POP), cell density, and scanning electron microscope (SEM) imaging. Samples were also collected for APase and NRase assays.

\section{DETERMINATION OF NITRATE REDUCTASE ACTIVITY}

Aliquots of $400 \mathrm{ml}$ were centrifuged $\left(2000 \mathrm{~g}, 4^{\circ} \mathrm{C}, 15 \mathrm{~min}\right)$, and the resulting pellets were snap frozen in liquid nitrogen and stored at $-80^{\circ} \mathrm{C}$. NRase was extracted by adding $500 \mu \mathrm{l}$ of a solution containing $0.20 \mathrm{M}$ phosphate buffer $(p H=8.20), 1 \mathrm{mM}$ dithiothreitol (DTT) and $0.50 \mathrm{M}$ methylenediaminetetra-acetic acid (EDTA) to each pellet. The resuspended material was sonicated on ice for nine 10 -s bursts (30 s intervals between bursts) using a VC300 Vibracell sonicator (Sonics and Materials, USA) with a $20-\mathrm{kHz}$ frequency, 50\% duty cycle and an output of $3(90 \mathrm{~W})$. The final extract was centrifuged again $\left(750 \mathrm{~g}, 4^{\circ} \mathrm{C}, 5 \mathrm{~min}\right)$, and the supernatant was used for the enzyme activity determination. NRase assays were developed according to Rigobello-Masini et al. (2006). Tests were carried out in triplicate in $1 \mathrm{ml}$ at $19^{\circ} \mathrm{C}$. The reaction mixture contained $100 \mu \mathrm{l}$ of crude extract, $10 \mathrm{mM} \mathrm{KNO}_{3}$ and $2 \mathrm{mM} \mathrm{MgSO}_{4}$ and was initiated by the addition of reduced nicotinamide adenine dinucleotide $(\mathrm{NADH})$ substrate to a final concentration of $0.40 \mathrm{mM}$. The NRase reaction was stopped after $15 \mathrm{~min}$ with $250 \mu \mathrm{l}$ of absolute ethanol at $0^{\circ} \mathrm{C}$ and with $50 \mathrm{mM}$ $\mathrm{ZnSO}_{4}$. Activity was estimated based on the final nitrate concentration, indicated by the formation of a red AZO product after the simultaneous addition of $100 \mu \mathrm{l}(0.10 \%$ weight in volume, w/v) sulphanilamide and $100 \mu \mathrm{l}(0.10 \% \mathrm{w} / \mathrm{v}) \mathrm{N}$-1-naphtyl ethylenediamine dihydrochloride (Nicholas and Nason, 1957). After these additions, the reaction mixture was centrifuged again $(21,000 \mathrm{~g}, 5 \mathrm{~min})$, and the supernatant taken for colorimetric 
Table 1 | Nutrient concentrations and carbon chemistry parameters of the media at the beginning and at the end of the experiment.

\begin{tabular}{|c|c|c|c|c|c|c|c|c|c|c|c|}
\hline & $\begin{array}{l}\text { Nutrient } \\
\text { condition }\end{array}$ & $\begin{array}{l}{\left[\mathrm{NO}_{3-}\right]} \\
\left(\mu \mathrm{mol} \mathbf{k g}^{-1}\right)\end{array}$ & $\begin{array}{l}{\left[\mathrm{PO}_{43-}\right]} \\
\left(\mu \mathrm{mol} \mathrm{kg}^{-1}\right)\end{array}$ & $\begin{array}{l}\text { DIC ( } \mu \mathrm{mol} \\
\left.\mathbf{k g}^{-}\right)\end{array}$ & $\begin{array}{l}\text { TA ( } \mu \mathrm{mol} \\
\left.\mathbf{k g}^{-}\right)\end{array}$ & $\mathrm{pH}_{\text {total }}$ & $\begin{array}{l}\mathrm{pCO}_{2} \\
\text { ( } \mu \text { atm) }\end{array}$ & $\begin{array}{l}{\left[\mathrm{HCO}_{3-}\right]} \\
\left(\mu \mathrm{mol} \mathrm{kg}{ }^{-}\right)\end{array}$ & $\begin{array}{l}{\left[\mathrm{CO}_{3-}\right]} \\
\left(\mu \mathrm{mol} \mathrm{kg}{ }^{-}\right)\end{array}$ & $\begin{array}{l}\mathrm{CO}_{2} \\
\left(\mu \mathrm{mol} \mathrm{kg}{ }^{-}\right)\end{array}$ & $\Omega-\mathrm{Ca}$ \\
\hline Initial ${ }^{a}$ & $\mathrm{R}$ & 161.2 & 3.5 & 1906 & 2230 & 8.18 & 258 & 1674 & 222 & 8 & 5.3 \\
\hline End $^{b}$ & & $149.0(10.4)$ & $3.0(0.1)$ & $1808(5)$ & $2141(4)$ & $8.21(0.00)$ & $225(2)$ & $1575(5)$ & $225(1)$ & $8(0)$ & $5.4(0.0)$ \\
\hline Initial & $\mathrm{R}$ & 154.4 & 4.1 & 2040 & 2221 & 7.90 & 555 & 1890 & 132 & 19 & 3.2 \\
\hline End & & $147.6(0.9)$ & $2.6(0.0)$ & 1937 (65) & $2113(7)$ & $7.91(0.01)$ & $519(9)$ & 1793 (5) & $127(2)$ & $17(0)$ & $3.0(0.0)$ \\
\hline Initial & $\mathrm{R}$ & 156.2 & 3.4 & 2238 & 2330 & 7.67 & 1073 & 2117 & 86 & 36 & 2.1 \\
\hline End & & $149.4(0.9)$ & $1.7(0.1)$ & 2102 (14) & $2179(12)$ & $7.64(0.01)$ & $1080(27)$ & 1990 (14) & $75(1)$ & $36(1)$ & $1.8(0.0)$ \\
\hline Initial & $-N$ & 3.7 & 3.6 & 1892 & 2221 & 8.19 & 250 & 1658 & 225 & 8 & 5.4 \\
\hline End & & $0.3(0.1)$ & $2.9(0.4)$ & $1734(4)$ & $2021(3)$ & $8.16(0.01)$ & $251(5)$ & $1534(5)$ & $192(3)$ & $8(0)$ & $4.6(0.1)$ \\
\hline Initial & $-\mathrm{N}$ & 3.1 & 3.5 & 2085 & 2308 & 7.99 & 464 & 1909 & 161 & 16 & 3.9 \\
\hline End & & $0.1(0.0)$ & $2.9(0.0)$ & 1917 (4) & $2111(5)$ & $7.95(0.00)$ & $465(4)$ & 1765 (3) & $137(1)$ & $16(0)$ & $3.3(0.0)$ \\
\hline Initial & $-N$ & 3.3 & 3.5 & 2195 & 2264 & 7.60 & 1229 & 2082 & 72 & 41 & 1.7 \\
\hline End & & $0.1(0.0)$ & $1.6(0.00)$ & $1958(30)$ & $1994(1)$ & $7.51(0.01)$ & $1358(25)$ & $1860(3)$ & $52(1)$ & $45(1)$ & $1.3(0.0)$ \\
\hline Initial & $-P$ & 158.8 & 0.2 & 1897 & 2217 & 8.18 & 256 & 1667 & 222 & 9 & 5.3 \\
\hline End & & $156.7(0.21)$ & $0.0(0.0)$ & $1790(7)$ & $2097(8)$ & $8.18(0.00)$ & $243(3)$ & $1573(7)$ & $209(2)$ & $8(0)$ & $5.0(0.0)$ \\
\hline Initial & $-P$ & 159.5 & 0.2 & 2169 & 2363 & 7.92 & 561 & 2004 & 147 & 19 & 3.5 \\
\hline End & & 153.3 (1.5) & $0.0(0.0)$ & 1890 (3) & 2109 (8) & $8.01(0.01)$ & 394 (14) & $1723(5)$ & $154(5)$ & $13(1)$ & $3.7(0.1)$ \\
\hline Initial & $-P$ & 152.7 & 0.2 & 2186 & 2241 & 7.57 & 1314 & 2075 & 67 & 44 & 1.6 \\
\hline End & & $151.5(0.2)$ & $0.0(0.0)$ & 2098 (3) & 2153 (3.3) & $0.57(0.00)$ & $1253(8)$ & 1992 (3) & $64.8(0.4)$ & $42(0)$ & $1.6(0.0)$ \\
\hline
\end{tabular}

${ }^{a}$ Average blank values at the beginning of the experiment, before the inoculation of the cells.

${ }^{b}$ Average values from the triplicates at the end of the experiment/values in brackets correspond to the standard deviation from the triplicates at the end of the experiment

$\boldsymbol{R}$, nutrient replete; $-\boldsymbol{N}$, nitrate limited; $-\boldsymbol{P}$, phosphate limited conditions.

analysis at $543 \mathrm{~nm}$. Absorbance values were converted to nitrate concentration using a calibration curve. Enzymatic activities were expressed in enzymatic units per total protein, where one unit of the enzyme activity (UEA) catalyzes the conversion of $1 \mu \mathrm{mol}$ of nitrate to nitrite. Total protein determinations were performed with a commercial kit (Thermo Scientific Pierce ${ }^{\circledR}$ BCA Protein Assay Kit).

\section{DETERMINATION OF ALKALINE PHOSPHATASE ACTIVITY}

APase is expressed on the cell surface of E. huxleyi (Dyhrman et al., 2006), allowing the activity assay to be performed on whole cells. Aliquots $(40 \mathrm{ml})$ of sample were centrifuged at $2000 \mathrm{~g}$ and $19^{\circ} \mathrm{C}$ for $15 \mathrm{~min}$, and the pellets were resuspended in $2.90 \mathrm{ml}$ of a solution containing 0.01 M Tris buffer $(p H=9.00), 0.05 \mathrm{M}$ $\mathrm{MgCl}_{2}$ and $0.01 \mathrm{M} \mathrm{CaCl}_{2}$. After resuspension, $100 \mu \mathrm{l}$ of $13.50 \mathrm{M}$ $p$-nitrophenilphosphate ( $p$-NPP; Sigma) substrate were added, and the mixture was incubated at $19^{\circ} \mathrm{C}$ for $20 \mathrm{~min}$. The reaction was stopped by the addition of $0.60 \mathrm{ml}$ of $1 \mathrm{M} \mathrm{NaOH}$, and samples were centrifuged again $\left(3000 \mathrm{~g}, 19^{\circ} \mathrm{C}, 15 \mathrm{~min}\right)$ before the absorbance of the supernatant at $410 \mathrm{~nm}$ was measured. Absorbance values were transformed to $p$-nitrophenol ( $p$-NP) concentration using a suitable calibration curve. One unit of enzymatic activity corresponds to $1 \mathrm{nmol}$ of $p$-NP produced per $10^{6}$ cells $\min ^{-1}$.

\section{GROWTH RATE AND COCCOSPHERE VOLUME}

Growth rate was determined with a standard exponential growth equation (Reynolds, 1984):

$$
\mu=\left(\operatorname{Ln}\left(N_{t}\right)-\operatorname{Ln}\left(N_{0}\right)\right) / t
$$

where $N_{0}$ and $N_{t}$ are the cell densities at the start and at the harvest day respectively, and $t$ corresponds to the length of incubation (in days). Cell density and estimated coccosphere (cell + coccoliths) volume were determined in triplicates using a Beckman Coulter Multisizer III with a $70 \mu \mathrm{m}$ aperture.

\section{COCCOLITH LENGTH}

Coccolith length was measured from SEM images. For SEM sample collection, a $25 \mathrm{~mm}$ MF 300 filter was soaked with a drop of dilute ammonium hydroxide, and a $0.22 \mu \mathrm{m}$ polycarbonate filter was placed on top. A few drops of culture were placed on the polycarbonate filter, and samples were dried on an open Petri dish $\left(37^{\circ} \mathrm{C}\right.$ for $\left.24 \mathrm{~h}\right)$. A section of the top filter was cut out and sputter-coated in a Hummer VI-A gold coater, and a grid of 100 images at $5000 \times$ magnification was taken at a random location on each filter using a LEO 1450 VP SEM with SmartSEM V05-1 software. At least 60 coccoliths were measured on consecutive images along their longest axis (defined as coccolith length).

\section{PARTICULATE MATTER ANALYSES}

POC and PON concentrations were measured using a Thermo Finnigan Flash EA1112 elemental analyzer with acetanilide standards at Plymouth Marine Laboratory (PML). Aliquots of $200 \mathrm{ml}$ were filtered through two pre-combusted $\left(400^{\circ} \mathrm{C}, 4 \mathrm{~h}\right) \mathrm{MF} 300$ filters ( $25 \mathrm{~mm}$ glass microfiber $0.70 \mu \mathrm{m}$ pore size, Fisherbrand). Filters were kept at $-20^{\circ} \mathrm{C}$ until required for analysis and fumed with sulphurous acid for $24 \mathrm{~h}$ in a desiccator chamber to remove inorganic carbon (Verardo et al., 1990). The filters were then dried at $60^{\circ} \mathrm{C}$ for $16 \mathrm{~h}$ and pelleted in pre-combusted 
aluminium foil (EMA; $100 \times 30 \mathrm{~mm}$ circles) following Hilton et al. (1986).

For PIC analysis, $200 \mathrm{ml}$ of medium was filtered through $0.20 \mu \mathrm{m} 47 \mathrm{~mm}$ diameter Nuclepore polycarbonate filters, previously rinsed twice with $5 \mathrm{ml}$ of dilute ammonium hydroxide solution ( $\mathrm{pH} \sim 9$ ), and washed again three times after filtering. Filters were stored in $50 \mathrm{ml}$ Falcon tubes at $-20^{\circ} \mathrm{C}$ until analysis. Samples (including blanks) were then weighed, and $15 \mathrm{ml}$ of $0.10 \mathrm{M}$ nitric acid were added and re-weighed to determine the acid volume. The filters were left in acid for $2-3 \mathrm{~h}$ with continuous shaking, after which $500 \mu \mathrm{l}$ of the acid leach was removed and centrifuged ( $6500 \mathrm{~g}$ for $6 \mathrm{~min}$ ). A $250 \mu \mathrm{l}$ aliquot of the supernatant was taken to determine elemental concentrations in a Varian Vista Pro ICP-OES. The $\mathrm{Ca}^{2+}$ per coccolithophore was calculated and extrapolated to PIC, assuming that all $\mathrm{Ca}^{2+}$ on the filters originated in $\mathrm{CaCO}_{3}$ (Fagerbakke et al., 1994). The precision of the method, assessed from periodical measurements $(n=11)$ of standards was $1.17 \%$ RSD.

POP was measured using a wet-oxidation method, as described by Raimbault et al. (1999). Medium aliquots $(200 \mathrm{ml})$ were filtered through a single pre-combusted $\left(400^{\circ} \mathrm{C}, 4 \mathrm{~h}\right) \mathrm{MF} 300$ filter ( $25 \mathrm{~mm}$ glass microfiber $0.70 \mu \mathrm{m}$ pore size, Fisherbrand). Samples were digested with sodium tetraborate and potassium persulphate and autoclaved before analysis in a Segmented Flow Auto Analyser (SEAL QuAAtro) at the National Oceanography Centre Southampton (NOCS), UK.

\section{MEDIA CHEMISTRY}

Samples $(20 \mathrm{ml})$ of media were collected for nutrient measurements by filtration through a $0.22 \mu \mathrm{m}$ Millex filter (Millipore, Billerica, MA, USA) and stored at $-20^{\circ} \mathrm{C}$ until analysis. Macronutrient concentrations were determined colorimetrically following Hansen and Koroleff (1999) using a Segmented Flow Auto Analyser (QuAAtro, SEAL Analytical) at the NOCS (UK).

Samples for carbonate chemistry were collected in $300 \mathrm{ml}$ borosilicate bottles and preserved in the dark with $\mathrm{HCl}$ at a final concentration of $2.510^{-3} \mathrm{M}$ to prevent microbial growth during storage. These samples were later analysed to determine TA and DIC using a Verstatile INstrument for the Determination of Total inorganic carbon and titration Alkalinity (VINDTA3C) at the NOCS. DIC was analysed using a colorimetric titration (coulometer 5011, UIC, USA), and TA was determined using a semi-closed cell titration (Dickson et al., 2007). The precision of the method, assessed daily from repeated measurements $(n \geq 5)$ on the same batch of seawater, was $2.7 \pm 1.6 \mu \mathrm{mol}$ $\mathrm{Kg}^{-1}$ for DIC and $0.78 \pm 0.78 \mu \mathrm{mol} \mathrm{Kg}{ }^{-1}$ for TA. The accuracy was controlled against Certified Reference Materials (from A. G. Dickslon, Scripps Institution of Oceanography, USA) measured at the beginning and end of each day of analysis applying a correction factor obtained from the difference between the certified and the measured values. The carbonate system was calculated from temperature, salinity, DIC, TA and nutrients using the "CO2SYS" macro (Lewis and Wallace, 1998). The equilibrium constants were from Mehrbach et al. (1973) and refitted by Dickson and Millero (1987). The $\mathrm{KSO}_{4}$ constants were from Dickson (1990), and a seawater $\mathrm{pH}$ scale was used.

\section{STATISTICAL ANALYSIS}

One way factor ANOVA was conducted using SPSS 17 (SPSS Inc., Chicago IL, USA). Linear correlation factors ( $r^{2}$ value) were calculated using Sigma Plot 11.0 version (Systat Software Inc.).

\section{LIMITATION OF THE EXPERIMENTAL APPROACH}

Our batch culture experimental design precludes a direct quantitative comparison of PON, POP, PIC, and POC quotas (pmol per cell ${ }^{-1}$ ) between $\mathrm{R}$ and $-\mathrm{P}$ or $-\mathrm{N}$ cultures. Unlike in $\mathrm{R}$ cultures, growth rates in the $-\mathrm{N}$ and $-\mathrm{P}$ treatments were not constant over the course of the experiment (see Langer et al., 2012; Langer et al., who used the same experimental approach). In nutrientlimited batch cultures, cells experienced an initial exponential nutrient-replete phase followed by a nutrient-limited phase when cell division rate decreased. Therefore, cellular quotas include cellular PIC and POC produced in both exponential and nutrientlimited periods. For this reason, these cannot be compared with cellular quotas under nutrient-replete conditions, where growth is constant and exponential during the experiment. Therefore, in this study, $\mathrm{R},-\mathrm{P}$, and - $\mathrm{N}$ cultures are treated as separate experiments and comparisons of cellular PIC and POC quotas can be drawn between $\mathrm{CO}_{2}$ treatments but only within the same nutrient condition. Within each nutrient-limiting condition, the initial nutrient concentrations for all the $\mathrm{CO}_{2}$ conditions were identical (see Table 1). Given that in -N and -P experiments cells were harvested 2 days after the end of the exponential growth phase, any differences in PIC and POC quotas between the $\mathrm{CO}_{2}$ treatments (within each nutrient condition) are only the result of different $\mathrm{CO}_{2}$ levels.

\section{RESULTS}

\section{ENZYMATIC ACTIVITY}

NRase activity was detected only under $\mathrm{R}$ conditions, and a linear increase in its activity $\left[r^{2}=0.79 ; F_{(1,7)}=26.4 ; p=0.01\right]$ was observed with increasing $\mathrm{CO}_{2}$ levels (Figure 1). This increase in

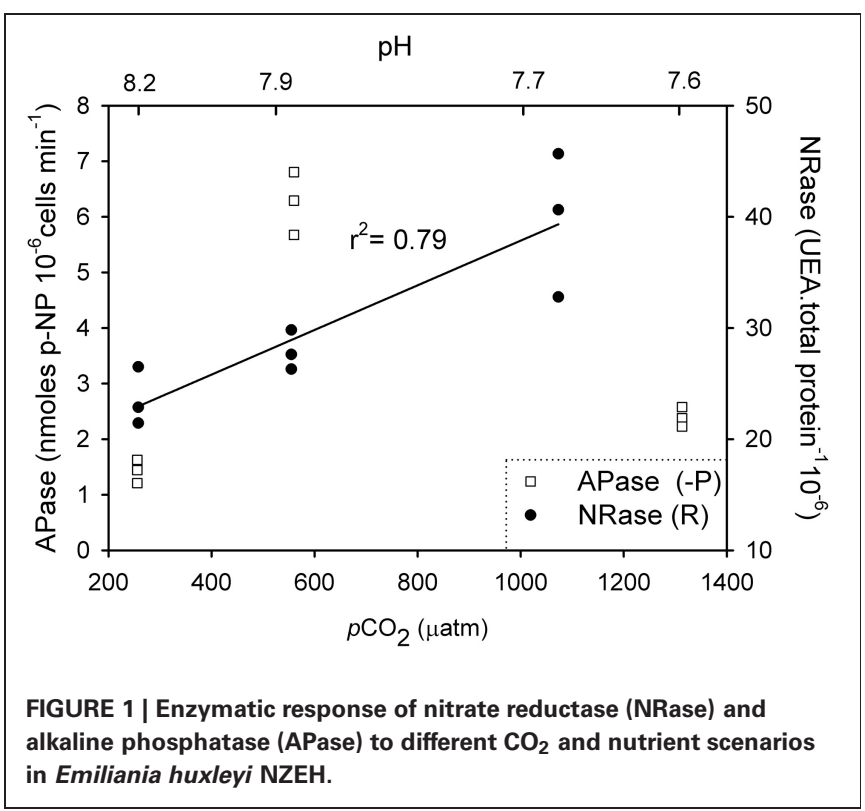


NRase activity was accompanied by a simultaneous increase in the cellular POC quota [Figure $2 ; r^{2}=0.74 ; F_{(2,7)}=20.5 ; p=0.02$ ]. APase activity was only detected in the $-\mathrm{P}$ cultures and showed a maximum rate of 6.25 nmoles of $p$-NP $10^{6}$ cells $\min ^{-1}$ at $561 \mu \mathrm{atm} \mathrm{CO}_{2}$. APase activity at 256 and $1314 \mu$ atm $\mathrm{CO}_{2}$ was 77 and $61 \%$ lower than at $561 \mu$ atm $\mathrm{CO}_{2}$ [Figure 1; $F_{(2,6)}=149.0$, $p<0.001]$. Cellular PIC quota showed a strong correlation with APase activity [Figure 3; $r=0.94 ; F_{(1,7)}=59.1 ; p<0.001$ ] but not with cellular POC (Figure 3).

\section{CELL ORGANIC AND INORGANIC MATTER QUOTAS}

In $\mathrm{R}$ cultures, both cellular $\mathrm{PON}$ and $\mathrm{POP}$ quotas increased significantly with increasing $\mathrm{CO}_{2}$ [Figure 4A; $F_{(2,6)}=19.28$, $\left.p=0.002(\mathrm{PON}) ; F_{(2,6)}=24.69, p=0.002(\mathrm{POP})\right]$. Cellular PIC and POC quotas were $\sim 70$ and $90 \%$ higher respectively
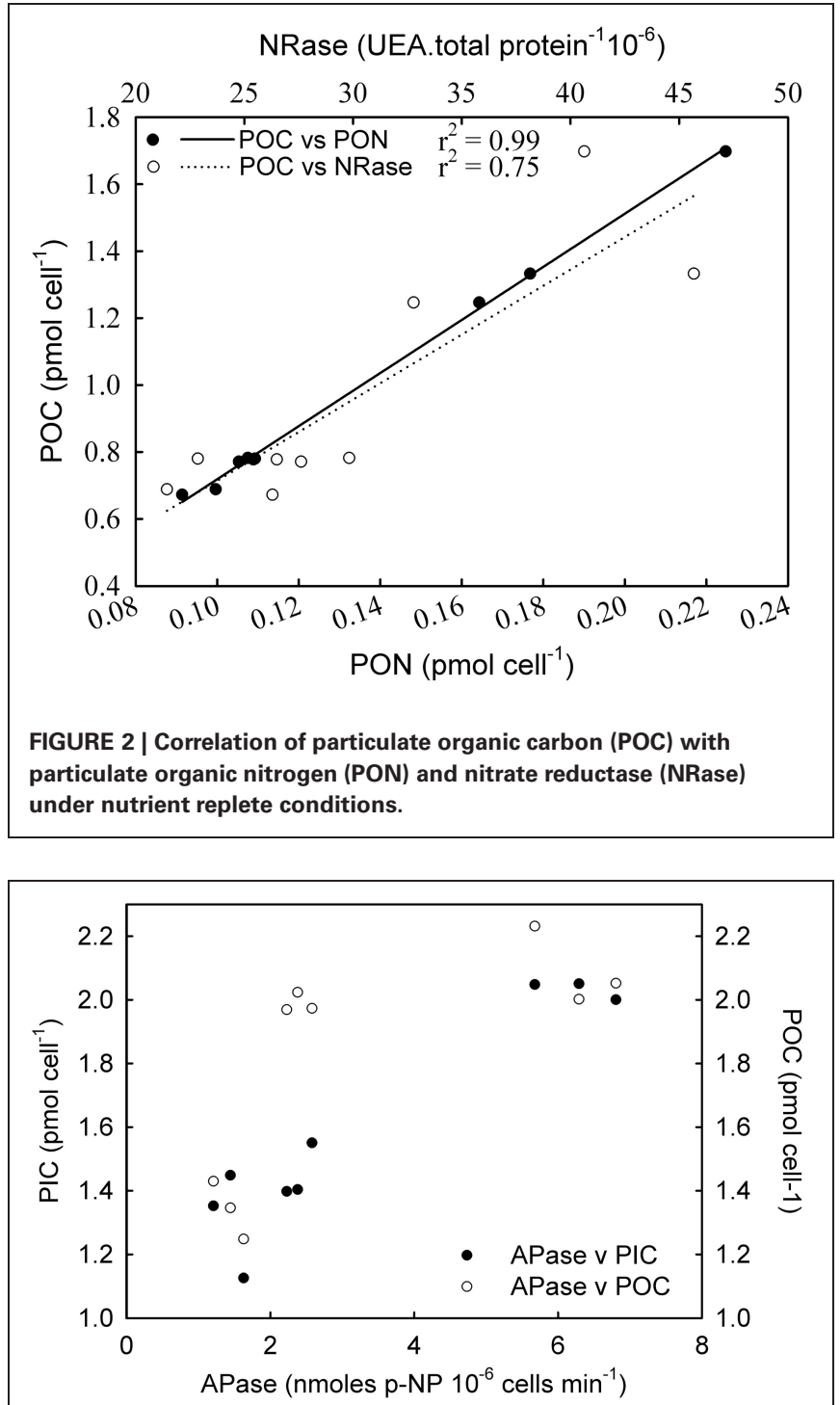

FIGURE 3 | Correlation of alkaline phosphatase (APase) with particulate organic carbon (POC) and particulate inorganic carbon (PIC) under phosphorus limited conditions.

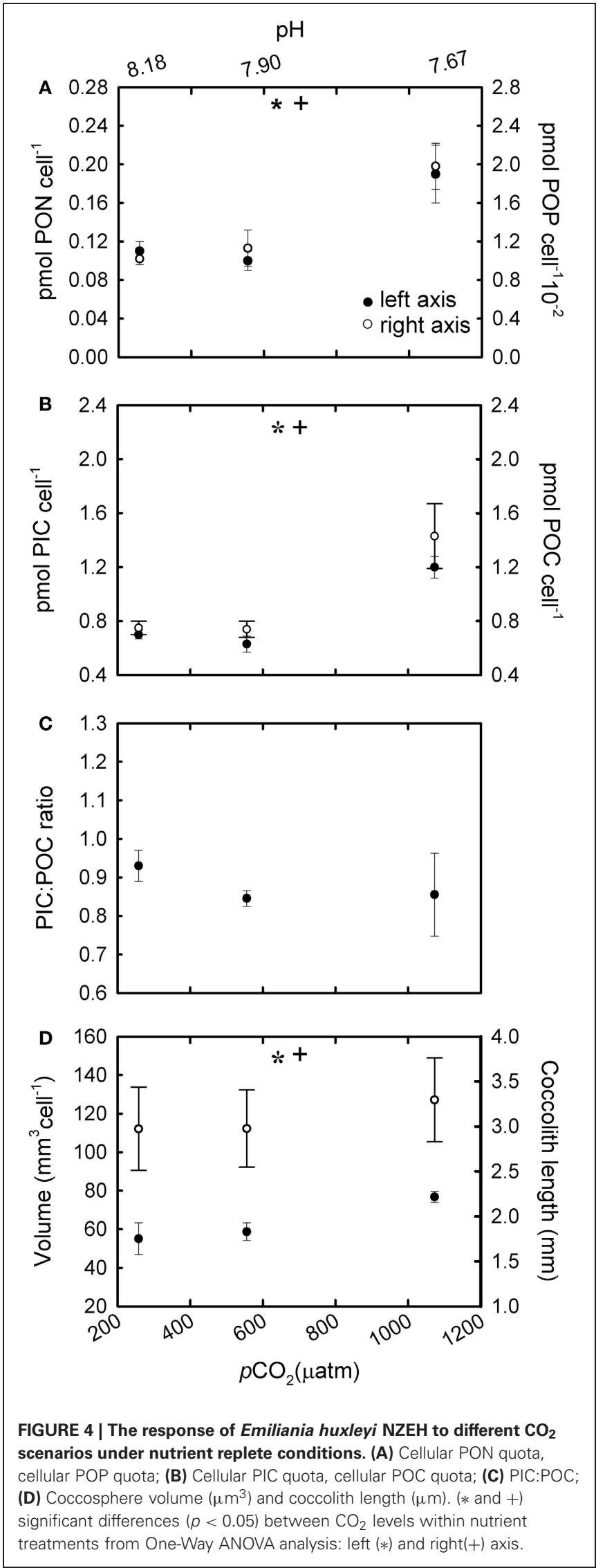


at the highest $\mathrm{CO}_{2}$ levels (555 and $1073 \mu$ atm) compared with cells grown under $\sim 258 \mu \mathrm{atm}$ of $\mathrm{CO}_{2}$ [Figure 4B; $F_{(2,6)}=80.37, \quad p \leq 0.001 \quad(\mathrm{PIC}) ; \quad F_{(2,6)}=10.65, \quad p=0.01$ (POC) $]$. In addition, cellular POC quotas increased in parallel to $\mathrm{PON}$ quotas under different $\mathrm{CO}_{2}$ conditions [Figure 2; $\left.r^{2}=0.99 ; \quad F_{(1,7)}=3596.4 ; p<0.001\right]$. The PIC:POC ratio did not change significantly with rising $\mathrm{CO}_{2}$ [Figure 4C; $F_{(2,6)}=1.41, p=0.315$ ] although a decreasing trend could be observed.

In - $\mathrm{N}$ cultures, nitrate in the culture media was almost completely depleted after 8-9 generations (Table 1). The cellular PON quota was less than half the concentration of the $\mathrm{R}$ cultures [Table 2; $\left.F_{(4,18)}=9.70, p \leq 0.001\right]$. Cellular PON quotas did not vary [Figure 5A; $F_{(2,6)}=1.22, p=0.361$ ] but POP quotas increased significantly [Figure 5A; $F_{(2,6)}=16.33, p=$ 0.004 ] with increasing $\mathrm{CO}_{2}$. Similarly, PIC quotas did no vary [Figure 5B; $F_{(2,6)}=0.35, p=0.72$ ], but POC quotas increased significantly with increasing $\mathrm{CO}_{2}$ levels [Figure $5 \mathbf{B} ; F_{(2,6)}=6.14$, $p=0.035]$. A significant decreasing pattern in PIC:POC was observed in $-\mathrm{N}$ cultures [Figure 5C; $F_{(2,6)}=9.07, p=0.015$ ] with increasing $\mathrm{CO}_{2}$.

In -P cultures, phosphate in the culture media was almost completely depleted after 8-9 generations (Table 1). The cellular POP quota was less than half the concentration of the $\mathrm{R}$ cultures [Table 2; $\left.F_{(4,18)}=7.39, p=0.001\right]$. Cellular PON quotas increased significantly [Figure 6A; $F_{(2,6)}=9.34, p=0.014$ ] but POP quotas did not vary [Figure 6A; $F_{(2,6)}=1.59, p=0.279$ ] with increasing $\mathrm{CO}_{2}$ conditions. The trend in cellular PIC quotas was not uniform and the most pronounced increase $(>100 \%)$ was observed at $561 \mu \mathrm{atm}$ of $\mathrm{CO}_{2}$ [Figure 6B; $F_{(2,6)}=37.03$, $p<0.001]$. Cellular POC quotas were $\sim 50 \%$ higher at the two highest $\mathrm{CO}_{2}$ levels ( $\sim 561$ and $\left.1314 \mu \mathrm{atm}\right)$ compared with cells grown under $256 \mu$ atm $\mathrm{CO}_{2}\left[F_{(2,6)}=10.742, p=0.010\right]$. In general, within each nutrient condition, the trend in PIC and POC quotas with $\mathrm{CO}_{2}$ varied when expressed as a function of coccosphere volume (Table 2). PIC:POC showed a decreasing pattern with increasing $\mathrm{CO}_{2}$ conditions [Figure 6C; $F_{(2,6)}=8.97$, $p=0.016]$.

\section{COCCOLITH LENGTH AND COCCOSPHERE VOLUME}

Under the highest $\mathrm{CO}_{2}$ level used, coccolith length was $\sim 10 \%$ higher compared to the lowest $\mathrm{CO}_{2}$ condition for all the nutrient treatments [Figure 4D; $F_{(2,567)}=31.7, p<0.001(\mathrm{R})$; Figure 5D; $F_{(2,567)}=14.5, p<0.001(-\mathrm{N})$; Figure 6D; $F_{(2,567)}=$ 43.8, $p<0.001(-\mathrm{P})$ ]. Coccosphere volume increased by $\sim 39 \%$ over the $\mathrm{CO}_{2}$ range considered under $\mathrm{R}$ conditions [Figure 4D; $\left.F_{(2,6)}=12.8, p=0.007\right]$. No differences in coccosphere volume were observed under $-\mathrm{N}$ conditions for all the $\mathrm{CO}_{2}$ levels tested [Figure 5D; $\left.F_{(2,6)}=2.1, p=0.207\right]$. The highest coccosphere volume under $-\mathrm{P}$ conditions was observed at $561 \mu$ atm of $\mathrm{CO}_{2}$

[Figure 6D; $F_{(2,6)}=37.5, p<0.001$ ].

\section{DISCUSSION}

\section{NUTRIENT UTILIZATION: ALKALINE PHOSPHATASE AND NITRATE REDUCTASE}

This is the first study to investigate E. huxleyi APase and NRase activities under varying $\mathrm{CO}_{2}$ levels. APase was only detected in -P

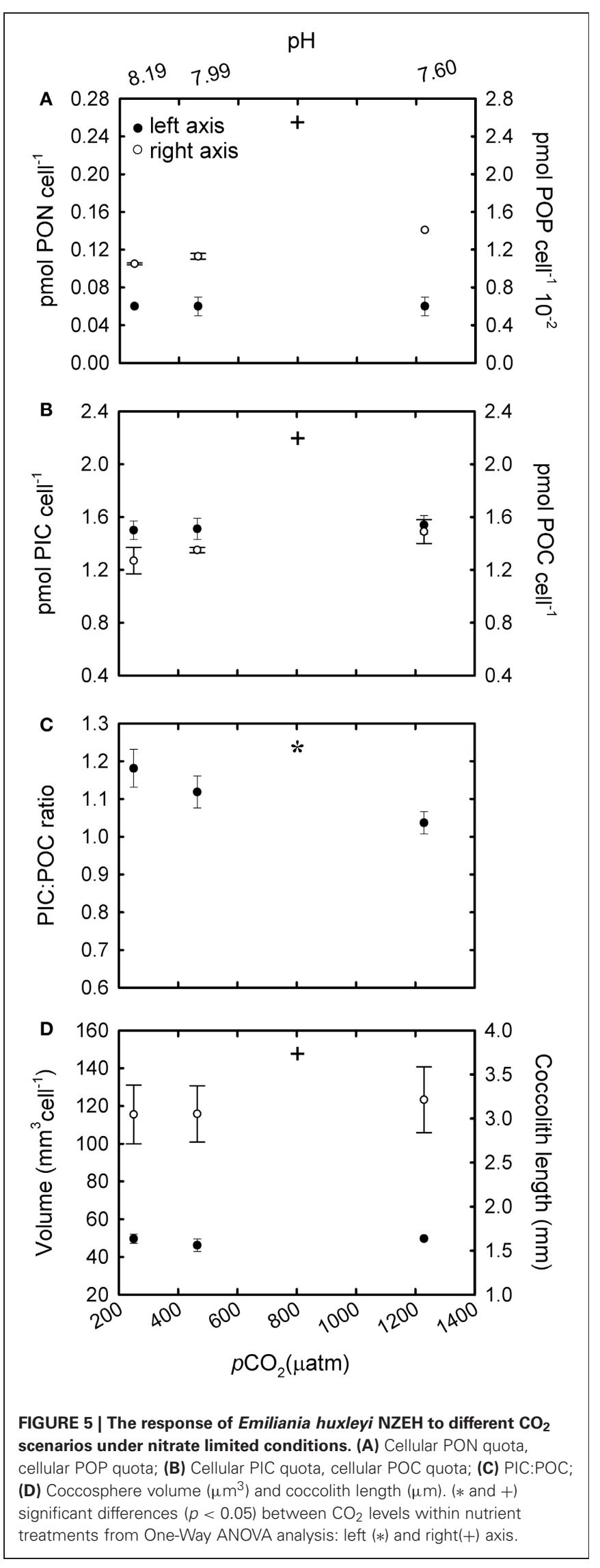




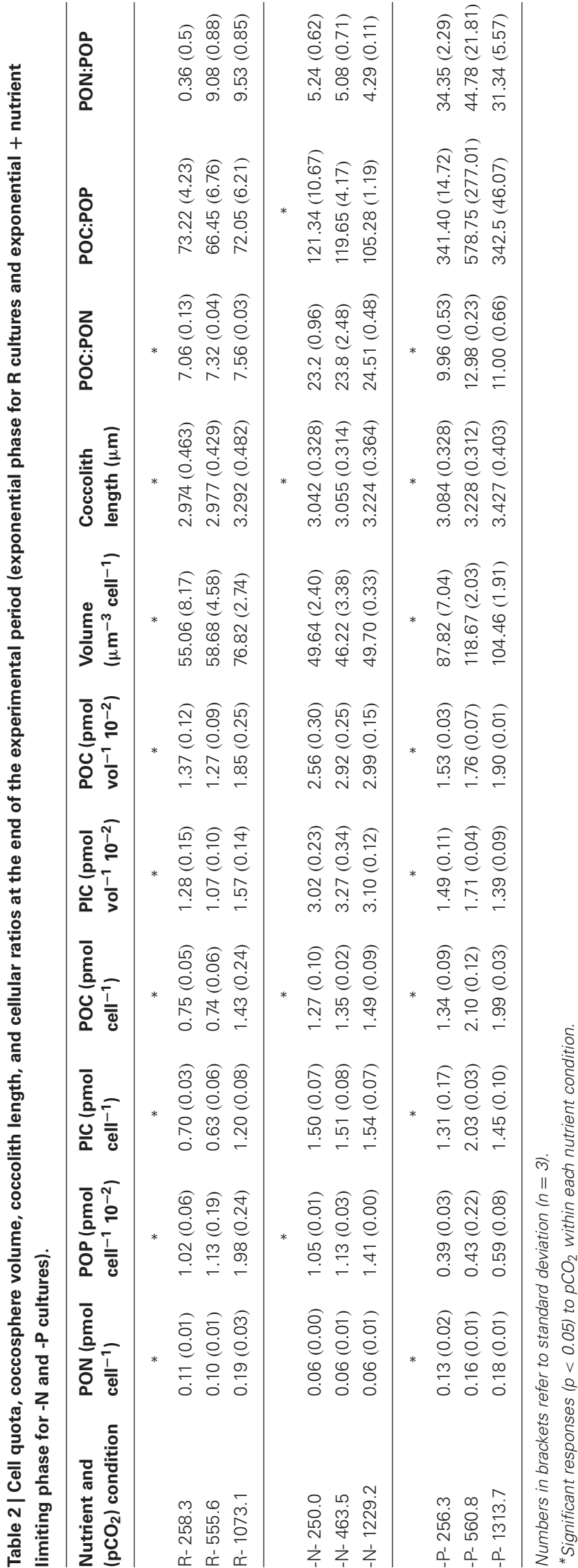
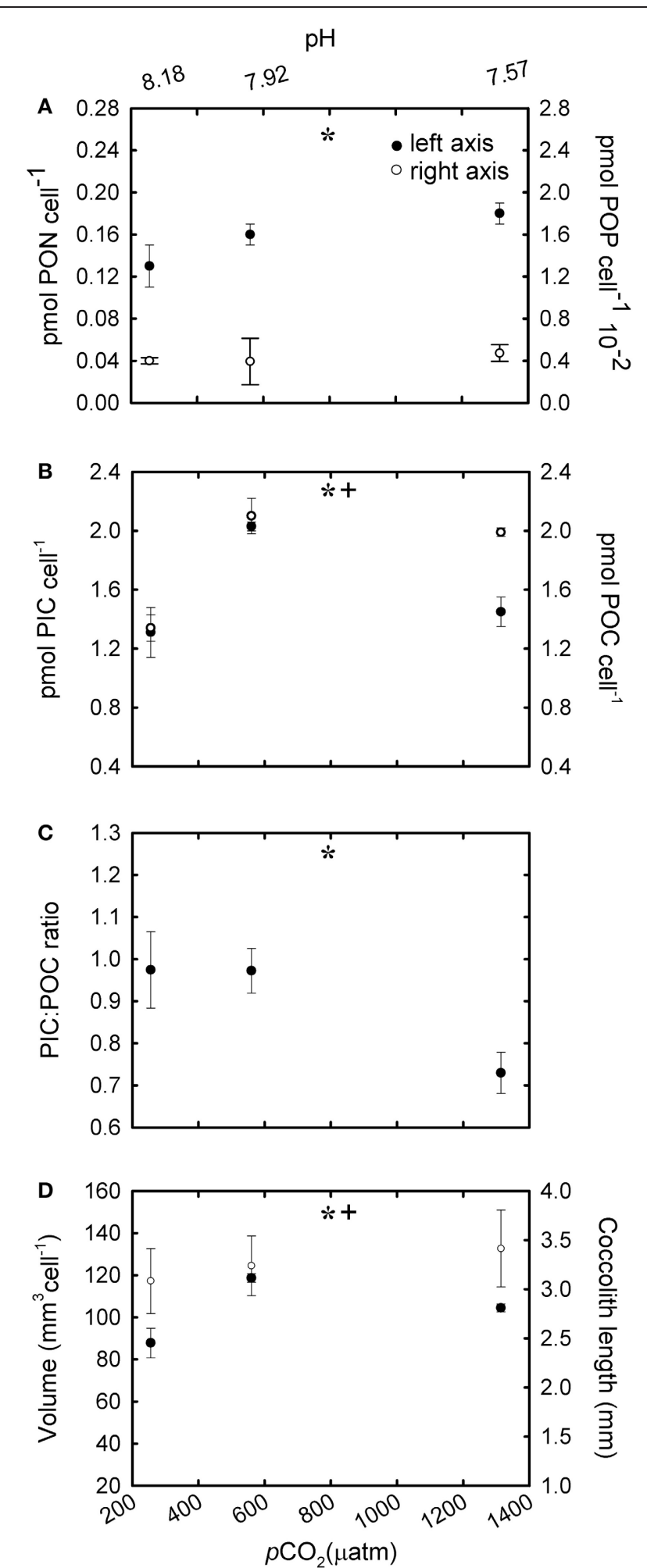

FIGURE 6 | The response of Emiliania huxleyi NZEH to different $\mathrm{CO}_{2}$ scenarios under phosphate limited conditions. (A) Cellular PON quota, cellular POP quota; (B) Cellular PIC quota, cellular POC quota; (C) PIC:POC; (D) Coccosphere volume $\left(\mu \mathrm{m}^{3}\right)$ and coccolith length $(\mu \mathrm{m}) .(*$ and +$)$ significant differences $(p<0.05)$ between $\mathrm{CO}_{2}$ levels within nutrient treatments from One-Way ANOVA analysis: left (*) and right(+) axis. 
cultures since APase activity is typically enhanced by phosphorus limitation. This enzyme allows phytoplankton to overcome phosphorus starvation by hydrolysing phosphate from esters in the dissolved organic phosphorus pool. APase activity showed a clear response to $\mathrm{CO}_{2}$ partial pressure, and its maximum activity was found at $561 \mu \mathrm{atm} \mathrm{CO}_{2}$ (Figure 1). Very little is known about the effect of $\mathrm{CO}_{2}$ in APase activities and phytoplankton (Tanaka et al., 2008; Endres et al., 2013), and the only study with E. huxleyi focused on the effect of $\mathrm{pH}$ (Xu et al., 2006). Since both $\mathrm{CO}_{2}$ and $\mathrm{pH}$ covaried in this study, the independent effect of these two parameters in APase activity cannot be discerned. As APase activity is known to be affected by changes in $\mathrm{pH}$ (Kuenzler and Perras, 1965), it is likely that $\mathrm{pH}$ is one, although maybe not the only, parameter affecting APase activity in this study.

A non-uniform response of APase activity to $\mathrm{CO}_{2}$ levels was observed, increasing from $256 \mu$ atm $\mathrm{CO}_{2}(p H=8.18)$ to $561 \mu$ atm $\mathrm{CO}_{2}(p H=7.92)$ but decreasing at the highest $\mathrm{CO}_{2}$ conditions (1314 $\mu \mathrm{atm}, p H=7.57)$ (Figure 1). This decline in activity may be the result of a $\mathrm{CO}_{2}$ threshold exceeding the $\mathrm{pH}$ upper limit for optimum APase activity. In a study on the cyanobacterium species Nodularia spumigena, APase activity increased with $\mathrm{CO}_{2}$ (Endres et al., 2013). However, direct comparison across studies is not always possible because of the different $\mathrm{CO}_{2}$ levels applied. For example, the maximum $\mathrm{CO}_{2}$ conditions used in their study was $\sim 700 \mu$ atm, probably still within the optimal $\mathrm{pH}$ range for this species. Additionally the thresholds of $\mathrm{pH} / \mathrm{CO}_{2}$ tolerance cannot be generalized as APase optimum $\mathrm{pH}$ is species-specific (Kuenzler and Perras, 1965) and also dependent on the species biogeography (Yamada and Suzumura, 2010). The decline in APase activity at high $\mathrm{CO}_{2}$ (1314 $\mu \mathrm{atm})$ suggests that the competitive ability of E. huxleyi to acquire phosphorus may be compromised in future more "acidic" oceans. However, the ecological implications of physiological results should be carefully considered given the high degree of genetic diversity among E. huxleyi strains (IglesiasRodriguez et al., 2006), the marked differences between strain maximum activities (Xu et al., 2010; Reid et al., 2011), as well as synergies with other levels of ecological organization.

NRase was only found in nutrient replete (R) cultures, when nitrate was present in the medium (Figure 1). Previous studies indicate a down-regulation of proteins involved in the acquisition and assimilation of inorganic nitrogen after nitrate depletion in E. huxleyi (Bruhn et al., 2010). Despite the presence of nitrate in the medium, NRase was absent when cultures grew in -P conditions. Since some regulatory mechanisms involved in nitrate assimilation include phosphorylation, phosphate limitation may be impairing this process (Beardall et al., 1998). NRase increased with rising $\mathrm{CO}_{2}$ levels under $\mathrm{R}$ conditions. The significant positive correlation between cellular POC and PON with NRase (Figure 2) could be explained by nitrogen and carbon metabolism being tightly coupled, such that a decrease in photosynthetic carbon fixation limits nitrogen assimilation (Hipkin et al., 1983; Turpin, 1991). It is possible that responses in NRase activity to ocean acidification may be species- and possibly strain-specific such as those found in higher plants (Fonseca et al., 1997; Matt et al., 2001) and phytoplankton species (Xia and Gao, 2005; Rigobello-Masini et al., 2006).

\section{PARTICULATE INORGANIC AND ORGANIC CARBON OUOTAS UNDER NUTRIENT-REPLETE CONDITIONS}

Both cellular POC and PIC quotas increased at high $\mathrm{CO}_{2}$ under nutrient replete $(\mathrm{R})$ conditions (Figure 4B). This increase was accompanied by slight increases in coccosphere volume and coccolith size (Figure 4D). The observed increase in cellular POC quotas at high $\mathrm{CO}_{2}$ concentrations has been observed in previous studies (e.g., Riebesell et al., 2000; Iglesias-Rodriguez et al., 2008; Langer et al., 2009) and suggests that this species could be carbon limited in the present ocean. Considering the low affinity of RUBISCO for $\mathrm{CO}_{2}$ and the poorly efficient carbon concentrating mechanisms in E. huxleyi (Paasche, 2002), any increase in available $\mathrm{CO}_{2}$ would increase the speed of carbon fixation, and thereby cellular POC quotas (Barcelos e Ramos et al., 2010). The observed increase in cellular PIC quotas with rising $\mathrm{CO}_{2} \mathrm{lev}$ els is in accordance with other studies using E. huxleyi NZEH (Iglesias-Rodriguez et al., 2008; Shi et al., 2009) but in disagreement with Hoppe et al. (2011). Discrepancies between studies with the same strain have also been found with strains others than NZEH (Langer et al., 2009; Hoppe et al., 2011) and with parameters others than PIC such as growth rate. Several explanations could reconcile the different outcomes observed between studies using the same strain; for example, differences in the experimental set up (i.e., carbon manipulation methods, number of generations under the experimental conditions, differences in temperature or light). The method of $\mathrm{pH}$ manipulation does not seem to be driving the reported differences between experiments according to results by Hoppe et al. (2011) and Shi et al. (2009), which revealed similar PIC responses to increasing $\mathrm{CO}_{2}$ using bubbling with different $\mathrm{CO}_{2}$ partial pressures or acid/base addition. Regarding the number of generations exposed to the manipulation, Barcelos e Ramos et al. (2010) showed a rapid response of E. huxleyi's metabolic properties (including PIC quotas) in response to ocean acidification. Finally, any differences in laboratorial culturing conditions, e.g., temperature and irradiance could give different outcomes. For example, results from this study and those by Iglesias-Rodriguez et al. (2008) and Shi et al. (2009) cannot be compared with those by Hoppe et al. (2011) because the temperature used in the latter was $4-5^{\circ} \mathrm{C}$ higher. Additionally, synergistic effects can give different outcomes; for example, trends in cellular PIC can change when $\mathrm{CO}_{2}$ levels are combined with different temperatures (Borchard et al., 2011) or light levels (Zondervan et al., 2002).

Different outcomes between studies using the same strain could also be explained by genetic differences between the cultured strains themselves. For example, there is evidence of shifts in phenotypic and genomic properties of strains over time under continuous culturing in the laboratory (Lakeman et al., 2009). Also, the potential for a strain to evolve properties that deviate from those of its original phenotype it is known to increase with time of exposure under the new growth conditions (Lakeman et al., 2009). Thus, comparisons between studies using the "same" strain must be conducted with caution. 


\section{PARTICULATE INORGANIC AND ORGANIC CARBON QUOTAS UNDER NUTRIENT-LIMITED CONDITIONS}

The ocean is a dynamic system and the physiological response of an independent species might differ depending on the combination of environmental parameters or stressors to which they are exposed, including nutrient limitation. Similarly to $\mathrm{R}$ cultures, the increase in POC quotas with increasing $\mathrm{CO}_{2}$ levels in both $-\mathrm{N}$ and $-\mathrm{P}$ cultures (Figures 5B, 6B) suggests that, under nutrient limitation, carbon may be rate-limiting for photosynthesis under the $\mathrm{CO}_{2}$ conditions commonly found in the open ocean. Our results are however, in disagreement with those using nitrogen (Sciandra et al., 2003) and phosphorous (Borchard et al., 2011) limiting conditions in a calcifying E. huxleyi strain, but in accordance with Leonardos and Geider (2005), using a non-calcifying E. huxleyi strain under high irradiance. These differences probably result from strain-specific responses and/or variations in laboratorial conditions. In contrast to cellular POC quotas, PIC quotas in $\mathrm{N}$ and -P cultures showed a different trend to that observed under $\mathrm{R}$ conditions. Interestingly, in - $\mathrm{N}$ cultures, $\mathrm{PIC}$ quotas remained constant under the different $\mathrm{CO}_{2}$ conditions suggesting that nitrogen metabolism may be decoupled from calcification. However, under phosphate limitation a decrease in PIC quotas was observed under the highest $\mathrm{CO}_{2}$ conditions (1314 $\left.\mu \mathrm{atm}\right)$. Interestingly, APase activity was tightly correlated with PIC quotas (Figure 3). However, elucidating the mechanistic effect of $\mathrm{CO}_{2}$ and phosphate limitation on calcification requires further work.

Different cellular elemental stoichiometry was found in the E. huxleyi NZEH strain under different environmental scenarios (Table 2). Stoichiometric mechanisms are known to play a very important role in defining the structure of the food web in aquatic ecosystems (Elser et al., 2000). Specifically, the biochemical composition of phytoplankton is known to affect grazing preference (Jones et al., 2002). Thus, changes in stoichiometry could influence the grazing-selection pressure, ultimately determining the prevalence of some strains versus others in future oceans. In addition, changes in cellular elemental stoichiometry should be taken into consideration when predicting the role of E. huxleyi in future biogeochemical cycles.

Unlike in the $\mathrm{R}$ manipulations, the PIC:POC ratios decreased with $\mathrm{CO}_{2}$ under both $-\mathrm{N}$ and -P conditions in the NZEH strain (Figures 5C, 6C), comparable to other E. huxleyi strains under nitrogen (Sciandra et al., 2003; Müller et al., 2012) and phosphorus (Borchard et al., 2011) limitation. This finding is important considering the geographic extent of oligotrophic oceanic waters and the importance of PIC:POC ratio in determining aggregate formation processes, properties and sinking velocities (Armstrong et al., 2002). The data presented here suggest that a $\mathrm{N}$ - and P-limited population in a high $\mathrm{CO}_{2}$ ocean would have a reduced PIC:POC ratio, which would increase the removal of $\mathrm{CO}_{2}$ as a combined effect of calcification (a source of $\mathrm{CO}_{2}$ ) and photosynthesis (a sink of $\mathrm{CO}_{2}$ ) (Frankignoulle et al., 1994). However, this could also reduce the net $\mathrm{CO}_{2}$ export to the deep ocean associated with the role of coccolith $\mathrm{CaCO}_{3}$ in forming aggregate as ballast (Armstrong et al., 2002; Biermann and Engel, 2010).

\section{COCCOLITH LENGTH AND COCCOSPHERE VOLUME}

Although coccolith length was correlated with $\mathrm{CO}_{2}$, coccosphere volume was better correlated with nutrient availability (Figures 4D, 5D, 6D). Coccosphere volume increased with rising $\mathrm{CO}_{2}$ under $\mathrm{R}$ conditions, but an $11 \%$ decrease in coccosphere volume was observed under the highest $\mathrm{CO}_{2}$ level in -P cultures, similar to previous studies with the E. huxleyi strain PML-B92/11 (Borchard et al., 2011). It is interesting to note that, unlike $\mathrm{R}$ and $-\mathrm{N}$ cultures, changes in POC quotas were not associated with changes in coccosphere volume in - $\mathrm{P}$ cultures. Additionally, maximum PIC quotas were observed at $561 \mu \mathrm{atm} \mathrm{CO}_{2}$ while coccolith length showed the highest values at $1314 \mu \mathrm{atm} \mathrm{CO}_{2}$. Similarly, in -N cultures, increased coccolith sizes did not correlate with PIC quotas, which were constant at all $\mathrm{CO}_{2}$ conditions. These results suggest that under nutrient limitation and at the highest $\mathrm{CO}_{2}$ condition, E. huxleyi might hold coccoliths bearing less calcite than under the lowest $\mathrm{CO}_{2}$ levels.

\section{IMPLICATIONS}

The E. huxleyi strain NZEH, whose coccolith production seemed to be resilient to ocean acidification, presents a different response to increasing $\mathrm{CO}_{2}$ depending on the nutrient condition. However, and similar to what was found under $\mathrm{R}$ conditions, this response still seems to be different to that observed in other E. huxleyi strains under $-\mathrm{N}$ and $-\mathrm{P}$ conditions. For the past few years, the ocean acidification community is urging the need for multiparametric experiments in order to gain a better insight into more realistic species-specific responses to environmental pressure. However, more strain-specific studies are also necessary in order to predict and understand the direction of future changes with a degree of certainty. This information is important to improve parameterizations in diagnostic and prognostic of global biogeochemical models.

\section{ACKNOWLEDGMENTS}

The authors thank the financial support given to Mónica Rouco by the Spanish Ministry of Science and by the Ramon Areces Fundation. We thank Edward Smith, John Gittins and Sonya Dyhrman for most helpful technical support and advice on enzyme assay protocols and laboratorial assistance. We thank Harry Elderfield and Mervyn Greaves for PIC analysis and Chris Daniels for his help with analysis of SEM samples. This research was supported by the "European Project on Ocean Acidification" (EPOCA) which received funding from the European Community's Seventh Framework Programme (FP7/2007-2013) under grant agreement $\mathrm{n}^{\circ} 211384$. This work was also funded in part by The European Research Council (ERC grant 2010-ADG-267931 to Harry Elderfield) and the Spanish Ministry of Science and Innovation (grant CTM2008-05680-C02-01). 


\section{REFERENCES}

Armstrong, R. A., Lee, C., Hedges, J. I., Honjo, S., and Wakeham, S. G. (2002). A new, mechanistic model for organic carbon flux in the ocean based on the quantitative association of POC with ballast minerals. Deep-Sea Res. II 49, 219-236. doi: 10.1016/S0967-0645(01)00101-1

Barcelos e Ramos, J., Müller, M. N., and Riebesell, U. (2010). Short-term response of the coccolithophore Emiliania huxleyi to abrupt changes in seawater carbon dioxide concentrations. Biogeosci. Discuss. 7, 177-186. doi: 10.5194/bg-7-1772010

Beardall, J., Johnston, A., and Raven, J. (1998). Environmental regulation of CO2-concentrating mechanisms in microalgae. Can. J. Bot. 76, 1010-1017. doi: 10.1139/b98-079

Beaufort, L., Probert, I., de GaridelThoron, T., Bendif, E. M., Ruiz-Pino, D., Metzl, N., et al. (2011). Sensitivity of coccolithophores to carbonate chemistry and ocean acidification. Nature 476, 80-83. doi: 10.1038/nature10295

Benner, I., and Passow, U. (2010). Utilization of organic nutrients by coccolithophores. Mar. Ecol. Prog. Ser. 404, 21-29. doi: 10.3354/ meps08474

Biermann, A., and Engel, A. (2010). Effect of $\mathrm{CO} 2$ on the properties and sinking velocity of aggregates of the coccolithophore Emiliania huxleyi. Biogeosciences 7, 1017-1029. doi: 10.5194/bg-7-1017-2010

Borchard, C., Borges, A., Händel, N., and Engel, A. (2011). Biogeochemical response of Emiliania huxleyi (PML B92/11) to elevated $\mathrm{CO} 2$ and temperature under phosphorus limitation: a chemostat study. J. Exp. Mar. Bio. Ecol. 410, 61-71. doi: 10.1016/j. jembe.2011.10.004

Bruhn, A., La Roche, J., and Richardson, K. (2010). Emiliania huxleyi (Prymnesiophyceae): nitrogen-metabolism genes and their expression in response to external nitrogen sources. J. Phycol. 46, 266-277. doi: 10.1111/j.15298817.2010.00809.x

De Bodt, C., Van Oostende, N., Harlay, J., Sabbe, K., and Chou, L. (2010). Individual and interacting effects of $\mathrm{pCO}_{2}$ and temperature on Emiliania huxleyi calcification: study of the calcite production, the coccolith morphology and the coccosphere size. Biogeosciences 7, 1401-1412. doi: 10.5194/bg-71401-2010

Dickson, A. (1990). Thermodynamics of the dissociation of boric acid in synthetic seawater from 273.15 to 18.15 K. Deep-Sea Res. A. 37, 755-766.

Dickson, A., and Millero, F. (1987). A comparison of the equilibrium constants for the dissociation of carbonic acid in seawater media. DeepSea Res. A. 34, 1733-1743. doi: 10.1016/0198-0149(87)90021-5

Dickson, A. G., Sabine, C. L., and Christian, J. R. (Eds.). (2007). Guide to Best Practices for Ocean $\mathrm{CO}_{2}$ Measurements, PICES Special Publication 3, 191.

Dyhrman, S. T., Haley, S. T., Birkeland, S. R., Wurch, L. L., Cipriano, M. J., and McArthur, A. J. (2006). Long serial analysis of gene expression for gene discovery and transcriptome profiling in the widespread marine coccolithophore Emiliania huxleyi. Appl. Environ. Microbiol. 72, 252-260. doi: 10.1128/AEM.72. 1.252-260.2006

Dyhrman, S. T., and Palenik, B. (2003). Characterization of ectoenzyme activity and phosphate-regulated proteins in the coccolithophore Emiliania huxleyi. J. Plankton Res. 25, 1215-1225.

Elser, J. J., Sterner, R. W., Galford, A. E., Chrzanowski, T. H., Findlay, D. L., Mills, K. H., et al. (2000). Pelagic C:N:P stoichiometry in a eutrophied lake: responses to a whole-lake food-web manipulation. Ecosystems 3, 293-307. doi: 10.1007/ s100210000027

Endres, S., Unger, J., Wannicke, N., Nausch, M., Voss, M., and Engel, A. (2013). Response of Nodularia spumigena to pCO2 - Part 2: exudation and extracellular enzyme activities. Biogeosci. Discuss. 9, 5109-5151.

Fagerbakke, K., Heldal, M., Norland, S., Heimdal, B., and Baatvik, H. (1994). Chemical composition and size of coccoliths from enclosure experiments and a Norwegian fjord. Sarsia 79, 349-355. doi: 10.1080/ 00364827.1994 .10413566

Feng, Y., Warner, M. E., Zhang, Y., Sun, Y., Fu, F.-X., Rose, J. M., et al. (2008). Interactive effects of increased $\mathrm{pCO}_{2}$, temperature and irradiance on the marinecoccolithophore Emiliania huxleyi (Prymnesiophyceae). Eur. J. Phycol. 43, 87-98. doi: 10.1080/ 09670260701664674

Fonseca, F., Browsher, C. G., and Stulen, I. (1997). Impact of elevated atmospheric $\mathrm{CO}_{2}$ on nitrate reductase transcription and activity in leaves and roots of Plantago major. Physiol. Plant. 100, 940-948. doi: $\quad 10.1111 /$ j.1399-3054.1997. tb00021.x
Frankignoulle, M., Canon, C., and Gattuso, J. P. (1994). Marine calcification as a source of carbon dioxide: positive feedback of increasing atmospheric $\mathrm{CO}_{2}$. Limnol. Oceanogr. 39, 458-462.

Gehlen, M., Gangsto, R., Schneider, B., Bopp, L., Aumont, O., and Ethe, C. (2007). The fate of pelagic $\mathrm{CaCO}_{3}$ production in a high $\mathrm{CO}_{2}$ ocean: a model study. Biogeosciences 4, 505-519.

Hansen, H. P., and Koroleff, F. (1999). "Determination of nutrients," in Methods of Seawater Analysis, eds K. Grasshoff, K. Kremling, and M. Ehrhardt (Weinheim: WileyVCH), 159-228. doi: 10.1002/ 9783527613984.ch10

Hilton, J., Lishman, J. P., Mackness, S., and Heaney, S. I. (1986) An automated method for the analysis of 'particulate' carbon and nitrogen in natural waters. Hydrobiologia 141, 269-271. doi: 10.1007/ BF00014221

Hipkin, C. R., Thomas, R. J., and Syrett, P. J. (1983). Effects of nitrogen deficiency on nitrate reductase, nitrate assimilation and photosynthesis in unicellular marine algae. Mar. Biol. 77, 101-105. doi: 10.1007/ BF00396306

Hoppe, C. J. M., Langer, G., and Rost, B. (2011). Emiliania huxley shows identical responses to elevated $\mathrm{pCO}_{2}$ in TA and DIC manipulations. J. Exp. Mar. Biol. Ecol. 406, 54-62. doi: 10.1016/j.jembe. 2011.06.008

Iglesias-Rodriguez, M. D., Halloran, P. R., Rickaby, R. E. M., Hall, I. R., Colmenero-Hidalgo, E., Gittins, J. R., et al. (2008). Phytoplankton calcification in a high- $\mathrm{CO}_{2}$ world. Science 320, 336-340. doi: 10.1126/ science. 1154122

Iglesias-Rodriguez, M. D., Schofield O., Batley, J., and Medlin, L. K (2006). Intraspecific genetic diversity in the marine coccolithophore Emiliania huxleyi (prymnesiophyceae): the use of microsatellite analysis in marine phytoplankton population studies. J. Phycol. 42, 526-536. doi: 10.1111/j.1529-8817. 2006.00231.x

Jones, R. H., Flynn, K. J., and Anderson, T. R. (2002). Effect of food quality on carbon and nitrogen growth efficiency in the copepod Acartia tonsa. Mar. Ecol. Prog. Ser. 235, 147-156. doi: 10.3354/meps235147

Kester, D., Duedall, I., Connors, D., and Pytkowicz, R. (1967). Preparation of artificial seawater. Limnol. Oceanogr. 12, 176-179.

Kuenzler, E. J., and Perras, J. P. (1965). Phosphatases of marine algae. Biol.
Bull. 128, 271-286. doi: 10.2307/ 1539555

Lakeman, M. B., von Dassow, P., and Cattolico, R. A. (2009). The strain concept in phytoplankton ecology. Harmful Algae 8, 746-758. doi: 10.1016/j.hal.2008.11.011

Langer, G., Nehrke, G., Probert, I., Ly, J., and Ziveri, P. (2009). Strain-specific responses of Emiliania huxleyi to changing seawater carbonate chemistry. Biogeosciences 6, 2637-2646. doi: 10.5194/bg-6-2637-2009

Langer, G., Oetjen, K., and Brenneis, T. (2012). Calcification of Calcidiscus leptosporus under nitrogen and phosphorus limitation. J. Exp. Mar. Biol. Ecol. 413, 1131-1137. doi: 10.1016/j.jembe.2011.11.028

Leonardos, N., and Geider, R. J. (2005). Elevated atmospheric carbon dioxide increases organic carbon fixation by Emiliania huxleyi (Haptophyta), under nutrientlimited high-light conditions. J. Phycol. 41, 1196-1203. doi: 10.1111/j.1529-8817.2005.00152.x

Lewis, E., and Wallace, D. W. R. (1998). Program Developed for $\mathrm{CO}_{2}$ System Calculations. Rep. ORNL/CDIAC105, Carbon Dioxide Information Analysis Centre. Oak Ridge, TN: Oak Ridge National Laboratory, U.S. Department of Energy.

Litchman, E., Klausmeier, C. A., Miller, J. R., Schofield, O. M., and Falkowski, P. G. (2006). Multinutrient, multi-group model of present and future oceanic phytoplankton communities. Biogeosciences 3, 585-606. doi: 10.5194/bg-3-585-2006

Matt, P., Geige, rM., Walch-Liu, P., Engels, C., Krapp, A., and Stitt, M. (2001). Elevated carbon dioxide increases nitrate uptake and nitrate reductase activity when tobacco is growing on nitrate, but increases ammonium uptake and inhibits nitrate reductase activity when tobacco is growing on ammonium nitrate. Plant Cell Environ. 24, 1119-1137. doi: 10.1046/j.13653040.2001.00771.x

Mehrbach, C., Culberson, C., Hawley, J., and Pytkowicz, R. (1973). Measurement of the apparent dissociation constants of carbonic acid in seawater at atmospheric pressure. Limnol. Oceanogr. 18, 897-907.

Müller, M. N., Beaufort, L., Bernard, O., Pedrotti, M. L., Talec, A., and Sciandra, A. (2012). Influence of $\mathrm{CO}_{2}$ and nitrogen limitation on the coccolith volume of Emiliania huxleyi (Haptophyta). Biogeosci. Discuss. 9, 4979-5010. doi: 10.5194/ bg-9-4155-2012 
Nicholas, D. J. D., and Nason, A. (1957). Determination of nitrate and nitrite. Meth. Enzymol. 3, 982-984.

Paasche, E. (2002). A review of the coccolithophorid Emiliania huxleyi (Prymnesiophyceae), with particular reference to growth coccolith formation and calcificationphotosynthesis interactions. Phycologia 40, 503-529. doi: 10.2216/i0031-8884-40-6-503.1

Raimbault, P., Diaz, F., Pouvesle, W., and Boudjellal, B. (1999). Simultaneous determination of particulate forms of carbon, nitrogen and phosphorus collected on filters using a semi-automatic wet-oxidation method. Mar. Ecol. Prog. Ser. 180, 289-295.

Raven, J., Caldeira, K., Elderfield, H., Hoegh-Guldberg, O., Liss, P., Riebesell, U., et al. (2005). Ocean Acidification Due to Increasing Atmospheric Carbon Dioxide. London: The Royal Society.

Reid, E., Worthy, C. A., Probert, I., Ali, S. T., Love, J., Napier, J., et al. (2011). Coccolithophores: functional biodiversity, enzymes and bioprospecting. Mar. Drugs 9, 586-602. doi: 10.3390/ md9040586

Reynolds, C. S. (1984). The Ecology of Freshwater Phytoplankton. Cambridge: Cambridge University Press.

Riebesell, U., Fabry, V. J., Hansson, L., and Gattuso, J.-P. (2010). Guide to Best Practices for Ocean Acidification Research and Data Reporting. Luxembourg: Office for Official Publications of the European Union. doi: 10.2777/58454

Riebesell, U., Zondervan, I., Rost, B., Tortell, P., Zeebe, R. E., and Morel, F. (2000). Reduced calcification of marine plankton in response to increased atmospheric
$\mathrm{CO}_{2}$. Nature 407, 364-367. doi: $10.1038 / 35030078$

Riegman, R., Stolte, W., Noordeloos, A. A. M., and Slezak, D. (2000). Nutrient uptake and alkaline phosphatase (EC 3, 1:3, 1) activity of Emiliania huxleyi (Prymnesiophyceae) during growth under $\mathrm{N}$ and $\mathrm{P}$ limitation in continuous cultures. J. Phycol. 36, 87-96. doi: 10.1046/j.1529-8817. 2000.99023.x

Rigobello-Masini, M., Masini, J. C., and Aidar, E. (2006). The profiles of nitrate reductase and carbonic anhydrase activity in batch cultivation of the marine microalgae Tetraselmis gracilis growing under different aeration conditions. FEMS Microbiol. Ecol. 57, 18-25. doi: 10.1111/j.1574-6941. 2006.00106.x

Sarmiento, J. L., Hughes, T. M. C., Stouffer, R. J., and Manabe, S. (1998). Stimulated response of the ocean carbon cycle to anthropogenic climate warming. Nature 393, 245-249. doi: 10.1038/30455

Sciandra, A., Harlay, J., Lefevrre, D., Lemée, R., Rimmelin, P., Denis, M., et al. (2003). Response of coccolithophorid Emiliania huxleyi to elevated partial pressure of $\mathrm{CO}_{2}$ under nitrogen limitation. Mar. Ecol. Prog. Ser. 26, 111-122. doi: 10.3354/ meps261111

Shi, D., Xu, Y., and Morel, F. M. M. (2009). Effects of the $\mathrm{pH} / \mathrm{pCO}_{2}$ control method on medium chemistry and phytoplankton growth. Biogeosciences 6, 1199-1207. doi: 10.5194/bg-6-1199-2009

Tanaka, T., Thingstad, T. F., Løvdal, T., Grossart, H.-P., Larsen, A., Allgaier, M., et al. (2008). Availability of phosphate for phytoplankton and bacteria and of glucose for bacteria at different $\mathrm{pCO} 2$ levels in a mesocosm study. Biogeosciences
5, 669-678. doi: 10.5194/bg-5-6692008

Turpin, D. H. (1991). Effects of inorganic $\mathrm{N}$ availability on algal photosynthesis and carbon metabolism. J. Phycol. 27, 14-20. doi: 10.1111/j. 0022-3646.1991.00014.x

Tyrrell, T., and Merico, M. (2004). "Emiliania huxleyi: bloom observations and the conditions that induce them," in Coccolithophores from Molecular Processes to Global Impact, eds $\mathrm{H}$. R. Thierstein and J. R. Young (Heidelberg: Springer), 75-97.

Verardo, D., Froelich, P., and McIntyre, A. (1990). Determination of organic carbon and nitrogen in marine sediments using the Carlo Erba NA1500 Analyzer. Deep-Sea Res. A. 37, 157-165. doi: 10.1016/0198-0149 (90)90034-S

Xia, J.-R., and Gao, K.-S. (2005). Impacts of Elevated $\mathrm{CO}_{2}$ Concentration on biochemical composition, carbonic anhydrase, and nitrate reductase activity of freshwater green algae. J. Integr. Plant Biol. 47, 668-675. doi: 10.1111/j.1744-7909.2005.00114.x

$\mathrm{Xu}$, Y., Boucher, J. M., and Morel, F. M. M. (2010). Expression and diversity of alkaline phosphatase EHAP1 in Emiliania Huxley (Prymnesiophyceae). J. Phycol. 46, 85-92. doi: 10.1111/j.1529-8817. 2009.00788.x

Xu, Y., Wahlund, T. M., Feng, L., Shaked, Y., and Morel, F. M. M. (2006). A novel alkaline phosphatase in the coccolithophore Emiliania huxleyi (Prymnesiophyceae) and its regulation by phosphorus. J. Phycol. 42, 835-844. doi: 10.1111/j.1529-8817. 2006.00243.x

Yamada, N., and Suzumura, M. (2010). Effects of seawater acidification on hydrolytic enzyme activities.
J. Oceanogr. 66, 233-241. doi: 10.1007/s10872-010-0021-0

Zachos, J., Pagani, M., Sloan, L., Thomas, E., and Billups, K. (2001). Trends, rhythms, and aberrations in global climate $65 \mathrm{Ma}$ to present Science 292, 686-693. doi: 10.1126/ science. 1059412

Zondervan, I., Rost, B., and Riebesell, U. (2002). Effect of $\mathrm{CO} 2$ concentration on the PIC/POC ratio in the coccolithophore Emiliania huxleyi grown under light-limiting conditions and different daylengths. J. Exp. Mar. Biol. Ecol. 272, 55-70. doi: 10.1016/S0022-0981 (02)00037-0

Conflict of Interest Statement: The authors declare that the research was conducted in the absence of any commercial or financial relationships that could be construed as a potential conflict of interest.

Received: 04 February 2013; accepted: 29 May 2013; published online: 18 June 2013.

Citation: Rouco M, Branson O, Lebrato $M$ and Iglesias-Rodríguez MD (2013) The effect of nitrate and phosphate availability on Emiliania huxleyi (NZEH) physiology under different $\mathrm{CO}_{2}$ scenarios. Front. Microbiol. 4:155. doi 10.3389/fmicb.2013.00155

This article was submitted to Frontiers in Aquatic Microbiology, a specialty of Frontiers in Microbiology.

Copyright (c) 2013 Rouco, Branson, Lebrato and Iglesias-Rodríguez. This is an open-access article distributed under the terms of the Creative Commons Attribution License, which permits use, distribution and reproduction in other forums, provided the original authors and source are credited and subject to any copyright notices concerning any thirdparty graphics etc. 